\section{ROYAL RECOGNITION FOR CARDIFF}

Cardiff University's Violence and Society Research Group was among the winners of a Queen's Anniversary Prize for excellence in higher education, at a ceremony at St James's Palace, London recently. Her Majesty the Queen will present the award to the University at Buckingham Palace in February.

The research into violence, alcohol and late-night safety has been translated into practical action to tackle late-night injuries in city centres. The Director of the Violence and Society Research Group is Jonathan Shepherd, Professor of Oral and Maxillofacial Surgery at Cardiff University's School of Dentistry and a member of the BDJ's Board of Advisers. It was his early career research into the rates of alcohol-related facial injuries treated in the NHS which led him to focus his research on violence.

Professor Shepherd said, 'I first became concerned about this issue as a young surgeon treating the victims of facial injuries every week. It seemed amazing that many cases I saw were not being reported to the police. Over the years, my colleagues and I have worked to find practical solutions from healthbased research. It is a great privilege to receive this award, and hugely encouraging for our continuing work with our partners locally, nationally and internationally in preventing community violence.'

A key part of winning the award was the group's work in setting up the prototype Crime Reduction Partnership in Cardiff in 1996. Academics, health professionals, South Wales Police and Cardiff Council worked together to identify violence hot-spots.

In this period, Cardiff became the safest city of its size in the UK. Following Government legislation, many other communities have now adopted Cardiff's partnership model, now known in Wales as Community Safety Partnerships.

Other key achievements by the group include the use of anonymised accident and emergency data to identify trends in late-night violence, new programmes of care for violence victims at every stage of their treatment, including a new service for post traumatic stress, and research on 'glassing' injuries which has led to the introduction of toughened glass and plastic vessels in pubs and nightclubs.

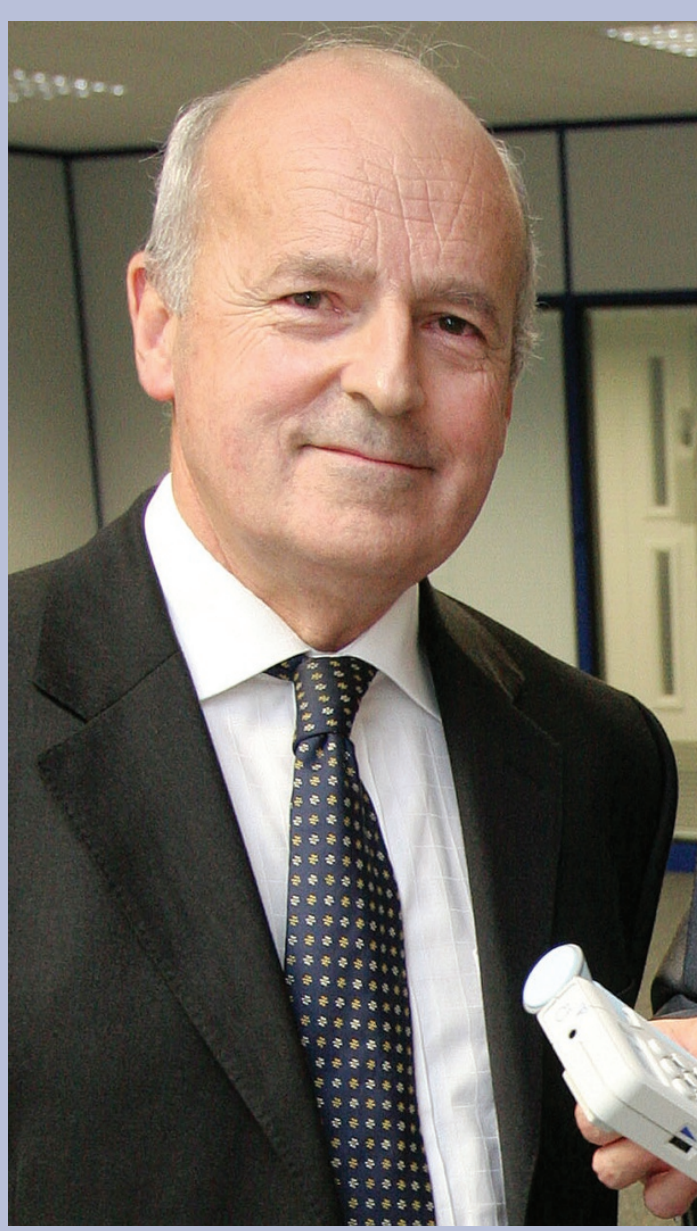

Professor Jonathan Shepherd is Director of the Violence and Society Research Group and Professor of Oral and Maxillofacial Surgery at Cardiff University's School of Dentistry

\title{
CALL FOR DENTISTS TO ENSURE THEY ARE USING THE SAFEST PRODUCTS
}

The Human Tissue Authority (HTA) has called on dentists and oral surgeons to ensure they are using products from licensed suppliers, nine months after new rules were announced for acellular bone products.

In the UK, suppliers of acellular bone or skin products for use in patient treatment must hold an HTA licence. The rules ensure that material which comes from human donors is tested for diseases such as HIV, hepatitis B and hepatitis $\mathrm{C}$ before use, and that any products derived from human tissues or cells that may pose a potential health risk can easily be recalled.

The rules apply to all acellular products used for patient treatment, including products derived from human skin used to promote wound healing after injury and products derived from human bone which may be used in dental or orthopaedic surgery. The HTA is now calling on dentists and oral surgeons in particular, who may not have high awareness of the regulation, to ensure they only obtain supplies of acellular products from HTA-licensed establishments.

Dr Sandy Mather, Director of Regulation at the HTA, said, 'Earlier this year we reviewed the risks to patients from bone and skin products following a number of cases where patient safety had been put at risk in Europe. The new regulation was announced in February 2009 with a license application deadline of 6 April 2009. Nine months after announcing the new regulation, we expect all suppliers of acellular products in the UK to hold an HTA license - it is unlawful to operate without one.
The rules put patient safety first and we would urge dentists and oral surgeons to ensure, if they are purchasing acellular products from UK suppliers, that the supplier holds an HTA licence.'

The Human Tissue Authority (HTA) is an independent watchdog that supports public confidence by licensing and inspecting organisations that store and use human tissue for purposes such as research, patient treatment, post-mortem examination, teaching, and public exhibitions. It also gives approval for organ and bone marrow transplants from living people through an independent assessment process.

A list of HTA-licensed establishments can be found on the HTA's website at http://www.hta.gov.uk/_db/_documents/ Licensed_Establishments_in_Human_ Tissue_Sector_-_November_2009.pdf. 